\title{
PENERAPAN TEKNOLOGI GPS UNTUK PELACAKAN POSISI HEWAN TERNAK (SAPI BALI) BERBASIS SMARTPHONE DI DESA PULAU PANGGUNG
}

\author{
Budi Harlianto, M. Farid, dan Suwarsono \\ Fakultas MIPA, Program Studi Fisika, Universitas Bengkulu \\ E-mail: b.harlianto@unib.ac.id
}

\begin{abstract}
ABSTRAK
Pengabdian kepada masyarakat penerapan sistem aplikasi teknologi GPS untuk pelacakan posisi hewan ternak (Sapi Bali) berbasis smartphone telah dilakukan di Desa Pulau Panggung Kecamatan Luas Kabupaten Kaur Provinsi Bengkulu. Kegiatan pengabdian kepada masyarakat ini diawali dengan pemberian penjelasan tentang sistem kerja GPS dan kegunaannya, memberikan pelatihan pengoperasian sistem pelacakan sapi menggunakan smartphone, pemasangan GPS pada Sapi dan pengujian selama 2 jam, serta melakukan validasi keakuratan GPS yang telah dipasang pada Sapi. Setelah diamati selama 2 jam tidak ada reaksi sapi yang menunjukkan ketidak nyamanan setelah dipasangi GPS, kemudian sapi tersebut dilepaskan untuk beraktivitas seperti biasanya. Proses pelacakan posisi sapi dapat dilakukan dengan tiga cara, pertama menggunakan aplikasi TRSTAR yang di download melalui playstore; kedua menggunakan pengiriman pesan (SMS); ketiga menggunakan menu panggil (call). Setelah proses pemasangan GPS dan sapi juga sudah beraktivitas seperti biasa, dilakukan pelacakan posisi baik melaui aplikasi, maupun melalui menu SMS dan call. Setelah mendapatkan informasi posisi sapi kemudian lakukan penelusuran sesuai dengan rute sesuai dengan tampilan maps pada smartphone pengguna/pemilik sapi (user). Hasil penelusuran menujukan posisi yang tepat antara yang tertera di maps dengan posisi sapi yang sebenarnya sehingga sangat membantu khalayak sasaran dalam mengetahui posisi sapi saat dicari untuk dikandangkan pada sore harinya.
\end{abstract}

Kata Kunci: Pelacakan Sapi, teknologi GPS, smartphone, Pulau Panggung.

\section{PENDAHULUAN}

Kabupaten Kaur merupakan kabupaten yang terletak di bagian paling selatan yang berjarak $\pm 186 \mathrm{~km}$ dari Kota Bengkulu (Ibu Kota Provinsi Bengkulu). Salah satu desa yang berada di Kabupaten Kaur adalah Desa Pulau Panggung secara geografis terletak pada $4{ }^{\mathrm{O}} 35$ 33" LS dan $103^{\circ} 17^{\prime} 03^{\prime \prime}$ BT yang berjarak $18 \mathrm{~km}$ dari Ibu Kota Kabupaten Kaur serta berjarak 1,5 km dari kantor Kecamatan Luas. Desa Pulau Panggung memiliki penduduk 1.384. jiwa dan $346 \mathrm{KK}$ dengan luas wilayah 4.186
Ha, pada umunya penduduknya bermata pencarian sebagai petani dengan jenis komoditi utamanya Karet, Kelapa Sawit, dan Kopi. Selain sebagai petani ada juga masyarakat yang memiliki aktivitas lain (pola nafkah ganda), seperti memelihara hewan ternak berupa Sapi, Kerbau, dan Kambing. Memelihara hewan ternak merupakan salah satu investasi yang banyak diminati oleh petani dibandingkan investasi jenis lain seperti membeli tanah atau kebun karena sapi atau kerbau akan lebih cepat terjual jika ada keperluan mendesak. Sapi 
Bali (Bos sondaicus) merupakan sapi Bali asli Indonesia yang diduga sebagai hasil domestikasi (penjinakan) dari banteng liar. Sebagian ahli yakin bahwa domestikasi tersebut berlangsung di Bali sehingga disebut sapi Bali (Guntoro, 2002). Jumlah petani di Desa Pulau Panggung yang memelihara hewan ternak (Sapi Bali) pada tahun 2017 sebanyak 6 KK (Kepala Keluarga) dengan jumlah total sapi yang dipelihara sebanyak 32 ekor. Sedangkan pada tahun 2018 mengalami peningkatan baik jumlah petani yang memeliharanya (12 KK) maupun jumlah sapi yang dipelihara (57 ekor) dan semuanya diternak dengan sistem liar atau dilepas pada siang hari dan dikandangi pada sore hari (BPS Kab. Kaur, 2018). Peningkatan jumlah tersebut disebabkan oleh semakin tingginya harga jual sapi namun peningkatan jumlah sapi tersebut juga menyebabkan semakin berkurangnya ketersediaan makanan di alam sehingga berakibat semakin jauhnya wilayah jelajah (home range) sapi. Hal tersebut salah satunya disebabkan oleh kurangnya pengetahuan tentang pengolahan pakan ternak, salah satu hijauan pakan ternak yang ada di desa Danda Jaya adalah rumbut Brachiaria Decumbens yang dapat dibuat silase pakan ternak (Sugiarti, 2020). Luasnya home range tersebut menimbulkan masalah berupa kesulitan dalam menemukan sapai pada saat mau dikandangi disore harinya. Luasnya home range sapi membutuhkan waktu yang lama dan energi yang banyak untuk menemukannya dan bahkan sering tidak ketemu sama sekali, jika tidak ketemu (tidak dikandangi) selama 1 atau 2 hari sapi tersebut bukanya mendekat tapi jelajahnya semakin jauh dan semakin sulit untuk ditemukan keberadaanya. Untuk mengatasi masalah tersebut biasaya petani akan mengalokasikan waktu pencarian sapi seharian penuh (mulai dari pagi sampai sore hari) dan kebiasaan itu tentunya mengganggu aktivitas bertaninya (berkebun atau bersawah).

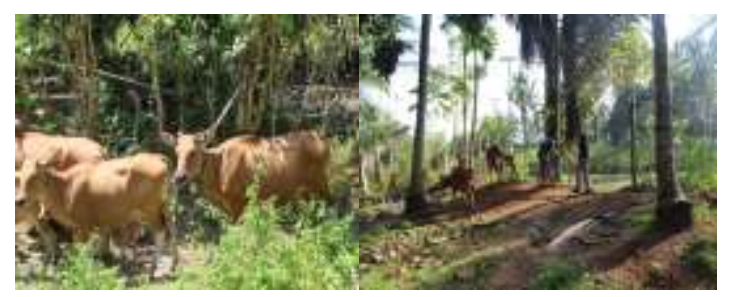

Gambar 1. Kondisi Sapi di Desa Pulau Panggung

Sebagai salah upaya untuk mengatasi permasalahan di atas perlu disosialisasikan teknologi GPS (Global Positioning System) untuk melacak keberadaan sapi peliharaan dengan cepat dan tepat. Penggunaan alat ini memudahkan masyarakat untuk mengetahui atau melacak posisi hewan secara langsung. Selain itu, terdapat perangkat yang mendukung kerja GPS yaitu, mikrokontroler sebagai komponen utama untuk mengolah data, internet sebagai komunikasi data bagi GPS dan perangkat android sebagai media 
informasi yang akan menampilkan data posisi hewan peliharaan. Android menyediakan platform terbuka bagi para pengembang untuk menciptakan aplikasi mereka sendiri untuk digunakan oleh bermacam peranti bergerak (Safaat, 2012). Selain menggunkan sistem Android untuk mengontrol suatu sistem dapat menggunakan komputer, namun metode ini memiliki kelemahan yaitu diharus mengelola dokumentasi tentang data versi terakhir, kurangnya jaminan konsistensi data utama dengan backup dan seringkali user lupa melakukan backup (Setiadi, 2015).

Sistem pelacakan posisi dapat juga disebut dengan sistem Locaton Based Service (LBS), ada dua definisi yang bisa menjelaskan tentang Location Based Service (LBS). Definisi Pertama: LBS adalah layanan informasi yang dapat diakses menggunakan piranti mobile melalui jaringan Internet dan seluler serta memanfaatkan kemampuan penunjuk lokasi pada piranti mobile (Mulyadi, 2010). Definisi Kedua: Layanan IP nirkabel yang menggunakan informasi geografis untuk memberikan layanan informasi lokasi kepada pengguna. Beberapa layanan aplikasi yang memberikan petunjuk posisi/lokasi piranti mobile berada (Roly, 2017).

Tujuan pengabdian kepada masyarakat ini adalah untuk memberikan informasi tentang alat bantu untuk melacak keberadaan hewan ternak secara cepat dan tepat dan mengadakan pelatihan instalasi (pemasangan) dan pengoperasian (penggunaan) GPS untuk melacak keberadaan hewan ternak sehingga mudah ditemukan saat hendak dikandangkan.

\section{METODE PELAKSANAAN}

\section{Lokasi dan waktu}

Pengadian kepada masyarakat ini dilakukan di Desa Pulau Panggung, Kecamatan Luas, Kabupaten Kaur yang dilakukan pada bulan Juni sampai Oktober 2019. Tahapan yang dilakukan:

\section{a) Alat dan Bahan}

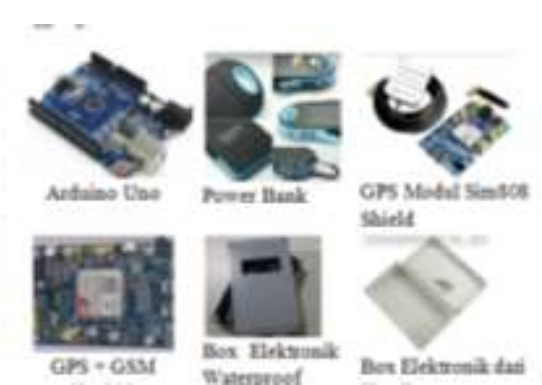

Gambar 2. Komponen Alat yang digunakan Metodologi pengabdian yang digunakan adalah rancang bangun sistem pelacak posisi sapi besbasis smartphone ini berisi tentang perancangan sistem dan implementasi sistem. Sistematik tata urutan program yang berjalan padasistem yang dibangun. Berikut adalah flowchart perangkat keras yang dibangun ditunjukan pada Gambar 5(a). Gambar 5(a) merupakan rangkaian alur kerja dari peragkat keras, mulai dari mikrokontroler akan menyala 
kemudian akan mengaktifkan GPS, ketika GPS telah mendapatkan request maka akan mengirimkan serial lokasi. GPS akan mengirimkan lokasi melalui wifi jika dalam jangkauan router dan akan dikirim melalui SMS apa bila diluar jangkauan router. Selanjutnya flowchart untuk perangkat lunak pada Gambar 5(b).

Tampilan pertama pada perangkat lunak akan menampilkan link posisi sapi, jika berhasil maka akan menampilkan daftar sapi dimana disitu terdapat form tambah sapi, form tersebut akan mengisi daftar sapi yang akan dilacak. Setelah memilih salah satu sapi yang akan dilacak di list sapi, maka akan menampilkan maps beserta titik lokasi sapi berada.

\section{b) Perancangan Sistem}

Perancangan perangkat keras ini dirangkai menyerupai kalung sapi, dimana bagian bawah leher sapi diposisikan alat pendeteksi berbentuk kotak hitam yang di dalamnya terdapat alat komponenkomponen elektronika. flowchart perangkat keras dan flowchart perangkat lunak dan Operator ditunjukan pada Gambar 3.
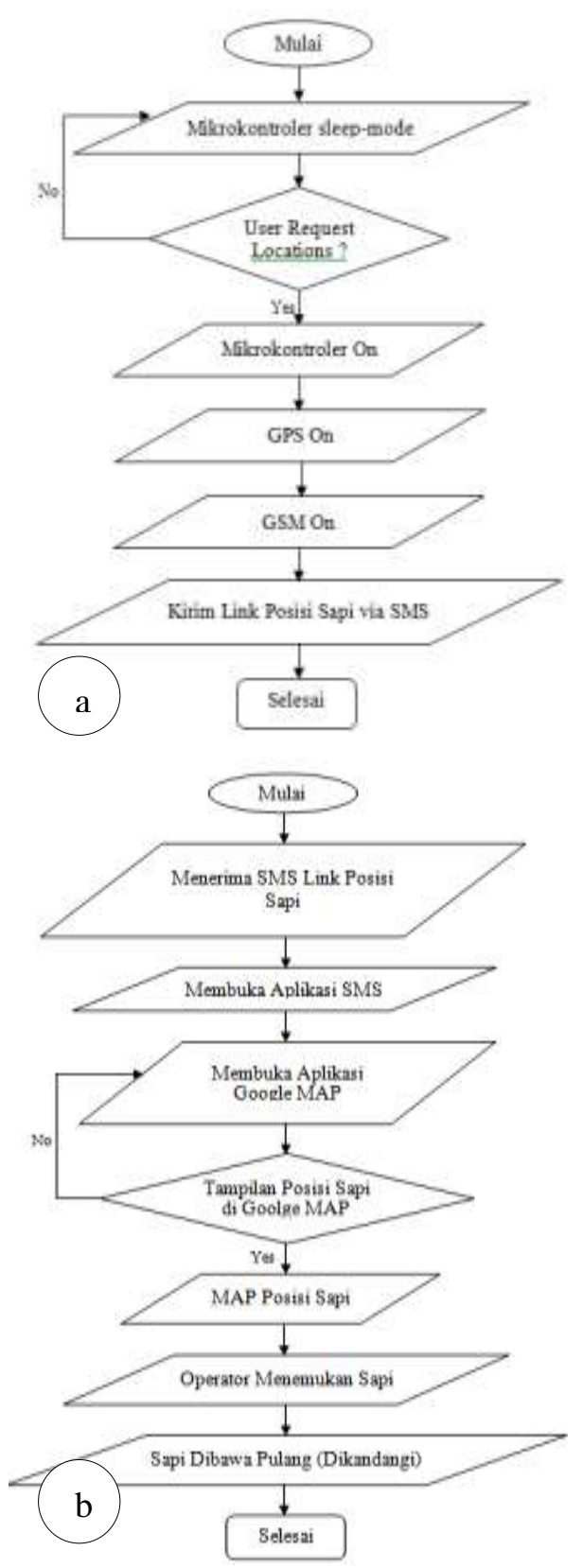

Gambar 3. (a) Flowchart perangkat keras;

(b) Flowchart perangkat lunak dan

Operator

\section{HASIL DAN PEMBAHASAN}

Berdasarkan pengabdian yang telah dilakukan mengasilkan alat yang dapat membantu peternak dalam memonitoring keberadaan atau posisi sapi secara langsung menggunakan smartphone. Sistem 
pelacakan tersebut dilakukan dengan menggunakan aplikasi yang ada pada smartphone milik peternak yang mampu melacak posisi sapi tersebut.

a. Pengujian Perangkat GPS pada Sapi

Pengujian ini dilakukan untuk mengetahui apakah perangkat yang dirancang dapat dipakai pada Sapi dengan nyaman. Pengujian ini dilakukan dengan mengamati reaksi dari Sapi yang dipasangkan perangkat selama 2 jam. Setelah diamati selama 2 jam tidak ada reaksi sapi yang menunjukkan ketidak nyamanan setelah dipasangi GPS dan kemudian sapi tersebut dilepaskan untuk mencari makan seperti biasanya. Pemasangan dan pengujian GPS pada Sapi bisa dilihat pada Gambar 4 dan Gambar 5.

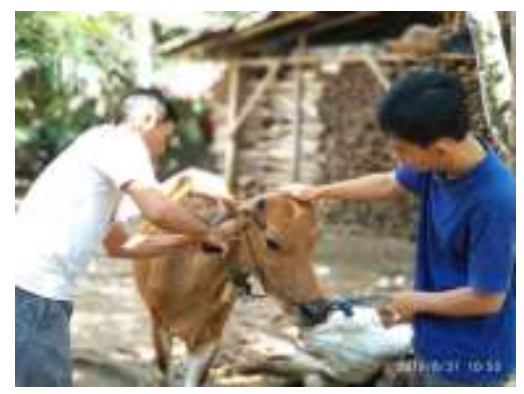

Gambar 4. Pemasangan Perangkat GPS pada Sapi

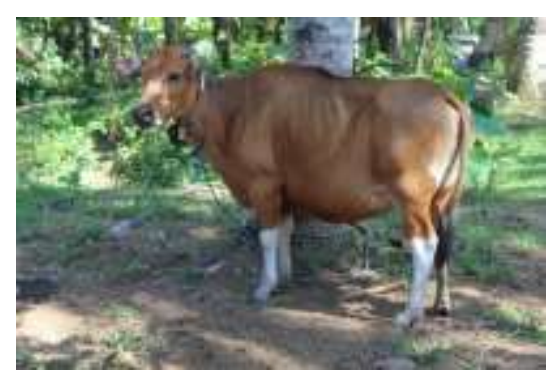

Gambar 5. Pengujian Perangkat GPS pada Sapi b. Pengujian Alat (Pengujian Sistem SMS)

Pengujian yang dilakukan dengan menggunakan sistem SMS mengahsilkan data seperti yang tertera pada Gambar 6 . Proses tersebut dilakukan dengan cara user/pengguna melakukan pengiriman SMS pada nomor Sim Card yang ada pada GPS yang dipasang pada sapi dengan mengetik G123456\# kemudian kirim, setelah beberapa menit kemudian akan secara otomatis dibalas dengan SMS/pesan yang berisikan koordinat lokasi sapi (lintang dan bujur), informasi baterai, serta link map yang dapat dibuka dengan aplikasi google map pada smartphone android.

Pengujian sistem SMS pada GPS dilakukan dengan berbagai titik lokasi yang dilakukan pada jarak $20 \mathrm{~m}, 800 \mathrm{~m}, 13.000 \mathrm{~m}$, dan 180.000 m. Pada jarak 20 m, 800 m, 13.000 $\mathrm{m}$ diperoleh hasil keakuratan penerimaan data yang sangat tinggi dimana masih menghasilkan 90\% kecepatan maksimal penerimaan data (dalam hitungan detik). Pengujian sistem yang dilakukan dengan berbagai jarak yang semakin jauh menghasilkan persentase keakuratan yang hampir sama. 


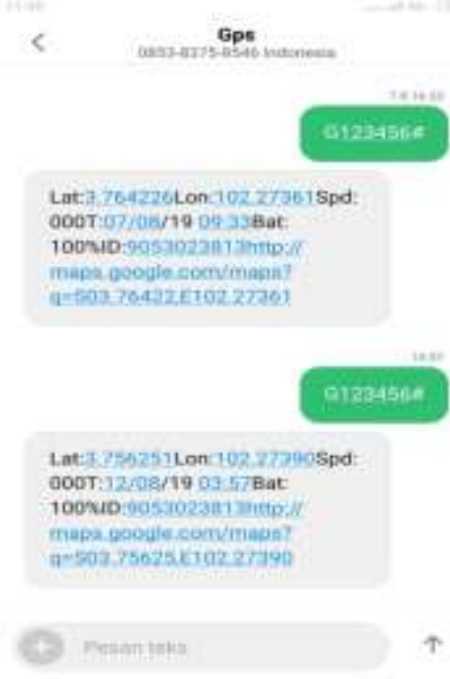

Gambar 6. Tampilan Pengujian SMS Pada GPS dan Smartphone

c. Pengujian permintaan lokasi melalui Panggilan/Call

Pengujian permintaan lokasi melalui menu panggilan/call dilakukan pada jarak yang berbeda-beda juga seperti halnya pengujian melalui SMS. Kita lakukan pemanggilan pada nomor (sim card) yang sudah dipasang pada GPS (setiap satu GPS memiliki satu nomor sim card), misalnya dalam pengabdian ini pada GPS 1 digunakan nomor 08117127713 sedangkan pada GPS2 digunakan nomor 08117127709. Setelah panggilan terhubung beberapa detik kemudian panggilan tersebut akan otomatis diputus (reject) dan beberapa saat aka nada notifikasi pesan yang berisikan lokasi GPS (sapi). SMS/pesan tersebut berisikan koordinat lokasi sapi (lintang dan bujur), informasi baterai, serta link map yang dapat dibuka dengan aplikasi google map pada smartphone android.
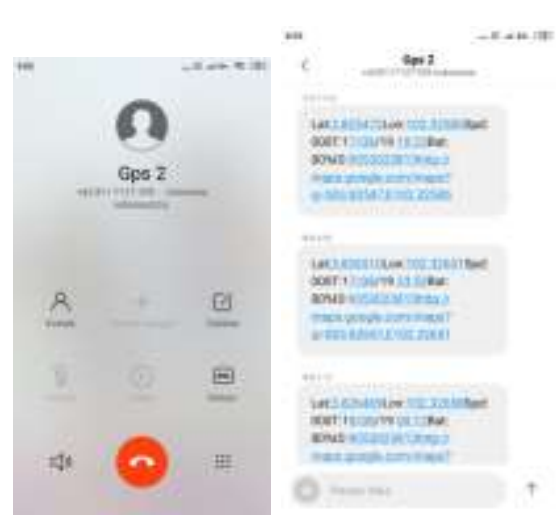

Gambar 7. Form Permintaan Lokasi Sapi melalui Telpon

\section{Proses Pelacakan Posisi Sapi}

Pelacakan Posisi Sapi melalui pengiriman pesan (SMS) dan menggunakan menu panggilan (call) hanya berbeda pada proses awalnya, sedangkan proses akhirnya memiliki kesamaan. Penggunaan menu SMS diawali dengan mengirimkan pesan (ketik G123456\#) ke nomor sim card yang sudah dipasang pada GPS kemudian secara otomatis SMS tersebut akan dibalas. Demikian juga proses pelacakan posisi sapi dengan menggunakan menu panggil (call), setelah panggilan tersebut tersambung secara otomatis akan dibalas dengan SMS. Proses berikutnya baik melalui menu SMS maupun melalui menu call adalah sama, dengan cara membuka link maps yang ada pada SMS tadi kemudian akan menunjukkan posisi sapi seperti ditunjukkan pada Gambar 8 . 


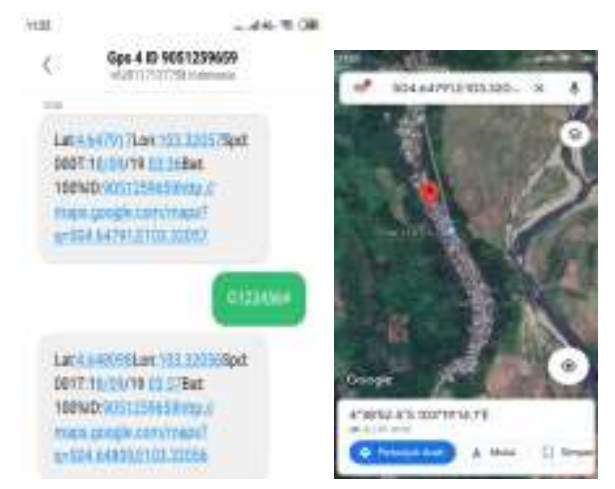

Gambar 8. Proses Pelacakan Sapi melalui menu SMS dan Call (SMS balsan dan hasil penelusuran maps.google.com)

d. Pengujian (Validasi) secara menyeluruh Proses selanjutnya adalah melakukan pengujian secara menyeluruh terhadap penggunaan GPS untuk melacak posisi sapi. Setelah proses pemasangan GPS dan sapi juga sudah beraktivitas seperti biasa, dilakukan pelacakan posisi baik melaui aplikasi, maupun melalui menu SMS dan call. Setelah mendapatkan informasi posisi sapi kemudian lakukan penelusuran sesuai dengan rute sesuai dengan tampilan maps pada smartphone pengguna/pemilik sapi (user) seperti yang ditunjukkan pada Gambar 8. Hasil penelusuran menujukan posisi yang tepat antara yang tertera di maps dengan posisi sapi yang sebenarnya sehingga sangat membantu khalayak sasaran dalam mengetahui posisi sapi saat dicari untuk dikandangkan pada sore harinya.

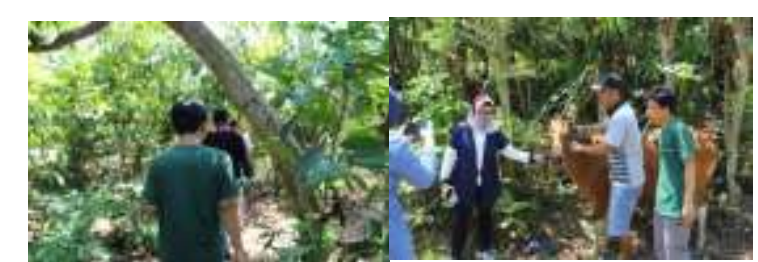

Gambar 9. Proses pengujian secara menyeluruh (penelusuran sampai menemukan sapi)
e. Pengujian keberhasilan khalayak sasaran

Keberhasilan khalayak sasaran dalam memahami kegunaan GPS untuk melacak posisi sapi serta cara menggunakan GPS tersebut secara mandiri dapat diketahui dari perbandingan jumlah peserta pengabdian ini yang dapat menggunakan GPS untuk melacak posisi sapi melalui smartphone terhadap jumlah total peserta yang mengikuti pengabdian ini dikurang dengan peserta yang tidak memiliki atau tidak dapat mengoperasikan smartphone. Jumlah total peserta yang mengikuti kegiatan ini sebanyak 20 orang, dari jumlah tersebut yang tidak memiliki smartphone sebanyak 8 orang. Berarti perbandinganya adalah $12: 12$ orang $=100 \%$ yang artinya semua peserta kegiatan yang memiliki dan dapat menggunakan smartphone berhasil melakukan proses pelacakan posisi sapi menggunakan smartphone nya. Hal tersebut didukung oleh cukup mudahnya proses yang dilakukan karena dapat dilakukan hanya dengan melakukan pengiriman SMS atau melakukan panggilan ke no sim card, 
seperti mereka melakukan pengiriman SMS dan panggilan telephone selama ini.
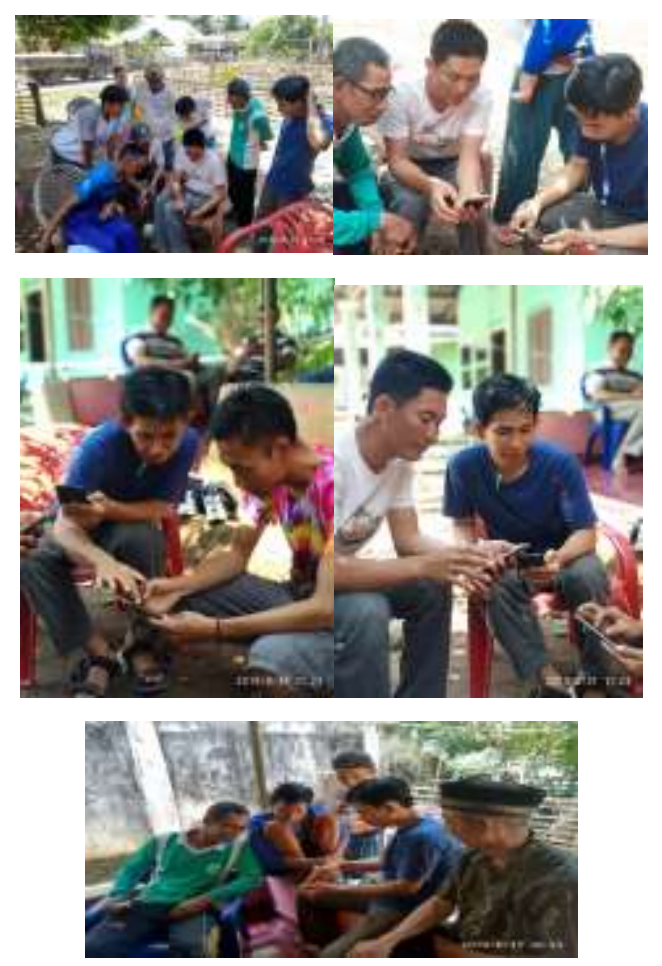

Gambar 10. Penjelasan Pengoperasian GPS untuk Lacak Sapi pada Khalayak Sasaran

\section{KESIMPULAN DAN SARAN}

\section{Kesimpulan}

Berdasarkan hasil penelitian dan pembahasan maka diperoleh kesimpulan: Sistem yang digunakan dalam pengabdian ini dapat melacak posisi sapi sehingga akan memudahkan pemilik sapi dalam pencarian dan dapat menggantikan peran tali yang dapat beresiko melilit badan sapi. Sitem dapat digunakan untuk memonitoring hewan ternak sapi secara langsung melalui smartphone sehingga dapat meningkatkan keamanan sapi dari tindak penjurian atau kehilangan.

\section{Saran}

Penggunaan material casing perangkat keras sebaiknya menggunakan bahan yang lebih kuat dan lebih aman. Rancangan sistem pelacak lokasi sapi otomatis ini secara fisik ukuranya masih terlalu besar dan perlu penyempurnaan sehingga ukurannya lebih kecil.

\section{DAFTAR PUSTAKA}

Guntoro, S, 2002. Membudidayakan Sapi Potong. Kanisius, Yogyakarta.

Kadir, Abdul, 2014, "Buku Pintar Pemrograman Arduino", Andi Offset, Yogyakarta.

Mulyadi, ST. 2010. Membuat Aplikasi untuk Android. Multimedia Center Publishing, Yogyakarta.

Roly, Subari, 2017. Sistem Pemantauan Lokasi Anak Menggunakan Metode Geofencing pada Platform Android. Teknologi \& Manajemen Informatika, Unmer Malang 3 (1), 0114.

Safaat, Nazrudin, 2012, “Android: Pemrograman Aplikasi Mobile Smartphone dan Tablet PC Berbasis Android", Informatika, Bandung.

Setiadi Budi, Fathur Rahman, dan Dwi Retnosari, 2015, Pelatihan Perakitan Komputer dan Installasi Sistem Operasi Windows 7, Jurnal Al-Ikhlas ISSN 24610992 Volume 1 Nomor 1, Oktober 2015.

Sugiarti, Fitriani Fitriani, dan Raga Samudera, 2020, Bimbingan Teknik Pembuatan Silase Pakan Sapi Bali Pada Kelompok Ternak Tinombala Desa Danda Jaya Kecamatan Rantau Badauh Kabupaten Batola, Jurnal AlIkhlas ISSN 24610992 Volume 6 Nomor 2, Desember 2020 